\title{
Encouraging Young Learners to Learn English through Stories
}

\author{
Cagri Tugrul Mart \\ Department of Languages, Ishik University, Erbil, Iraq \\ Tel: 964-750-3086122 E-mail: tugrulbey@hotmail.com
}

Received: February 9, 2012

Accepted: February 25, 2012

Published: May 1, 2012

doi:10.5539/elt.v5n5p101

URL: http://dx.doi.org/10.5539/elt.v5n5p101

\begin{abstract}
Reading is an important part of successful language acquisition. Motivating young learners to learn English through stories at an early age provides them the opportunity to widen their horizons and stimulate their early enthusiasm and enhance their awareness of the rich use of English. Stories are unquestionably a significant part of children's literacy development. When we read to our children, we do not confine them to academic excellence but extend into their emotional and behavioral learning (Ai Lian Kim, 2008). Reading at an early age is essential. Therefore, this article focuses on how to spark student's interest towards English through stories and how stories develop their language learning.
\end{abstract}

Keywords: Young learners, Reading, Learning English, Stories

\section{Introduction}

Storytelling is an accepted and widely used approach in the teaching of English language classroom. It represents a holistic approach to language teaching and learning founded on the understanding that learners need to interact with rich, authentic examples of the foreign language (Mourao, 2009). "In using stories in language teaching we are using something much bigger and more important than language teaching itself" (Wright, 2003: 7).

Story in its widest sense is also the carrier of life's messages and has, I believe, a vital part to play in the education of the young child, particularly in the development of language. I suggest that the teacher, working form a story "bank" rich in all manner of literary genres and crossings a variety of cultures, can produce the kind of learning environment which not only stimulates and carries the children along on the crest of their interest and enjoyment, but offers meaning potential without which the learning of language is rigid (Garvie, 1991: 56).

\section{Why Story Books?}

It is widely believed that literature-based instruction can positively influence the language development of primary school students (Morrow, 1992). Weinreich \& Bartlett claim that in children's literature " the child ... must be regarded as a necessary condition which the author consciously or unconsciously relates to in the creative process" (2000:127). For McDowell (1973), the term "children's literature" is applicable to books written for, and read by, that group referred to as children by any particular society. For Oberstein (1996: 17) "children's literature" is "a category of books the existence of which absolutely depends on supposed relationships with a particular reading audience: children". Hollindale (1997:30) defines "children's literature" as a body of texts with certain common features of imaginative interest, which is activated as children's literature by a reading event: that of being read by a child". According to Ghosn (2002: 172) "children's literature is fiction written for children to read for pleasure, rather than for didactic purposes". Huck et al. (1997: 5) children's literature is "the imaginative shaping of life and thought into the forms and structures of language". Galda and Cullinan (2002: 7) claim that literature "entertains and ... informs" and "it enables young people to explore and understand their world" and "enriches their lives and widens their horizons" and through literature children "learn about people and places on the other side of the world as well as ones down the street. They can travel back and forth in time to visit familiar places and people, to meet new friends, and to see new worlds. They can explore their own feelings, shape their own values, and imagine lives beyond the one they live". Tomlinson and Lynch-Brown (2002:2) define children literature as "good quality trade books written especially for children from birth to adolescence, covering topics of relevance and interest to children". Lewis (2001) states that there are good reasons for children reading picture-books:

Consider the fact that children born into the first years of the twenty-first century are likely to possess a richer and more deft understanding of visual imagery and its modes of deployment than any other generation in the history of humankind. Their world is saturated with imagines, moving and still, alone and in all manner of hybrid combinations with texts and sounds. This is the world in which they must function (p.59). 
Ghosn (2002: 173) summarizes the reasons why authentic literature is valuable for children:

- $\quad$ Authentic literature provides a motivating, meaningful context for language learning, since children are naturally drawn to stories.

- $\quad$ Literature can contribute to language learning. It presents natural language, language at its finest, and can foster vocabulary development in context. instruction.

Literature can promote academic literacy and thinking skills, and prepare children for the English-medium

- Literature can function as a change agent: good literature deals with some aspects of the human condition, can thus contribute to the emotional development of the child, and foster positive interpersonal and intercultural attitudes.

\section{How to Select Story Books?}

Brown (2004) claims that appropriate selections of children's literature give students exposure to new, illustrated vocabulary in context, provide repetition of key words and phrases that students can master and learn to manipulate and provide a sense of accomplishment.

"Smallwood (1988:66) recommends that criteria for the selection of children's literature for language learners should include "age-appropriate theme; simple language; limited use of metaphor and unfamiliar experiences; use of rhyme; unambiguous plot; realistic but simple dialogue; potential for reading aloud; brevity; and good illustrations". Smallwood adds these criteria some more:

- Does the book help meet curriculum objectives or enhance the thematic units being studied?

- Is the book's content appropriate to the children's age and intellectual level?

- Does the book use language that is at or slightly above the level of the learners?

- Does the book contain repeated, predictable language patterns?

- $\quad$ Are there clear illustrations that help the story?

In addition to these criteria Steinbeck (2008) lists the characteristics of using stories with young learners as:

- $\quad$ Stories should be action oriented

- $\quad$ Stories should be personal (the use of familiar characters, the pre- and post- activities should make use of the personalization technique.

- $\quad$ Stories should not be too detailed, both in terms of the story and the visuals used.

- $\quad$ Stories should allow for context extension.

- Stories should use comprehensible input (the language that is at the right cognitive and linguistic level) so that the output is more structured.

Heide Niemann (2002), when selecting a story book for young learners, states that the following questions will support parents to direct their ways.

- $\quad$ Are different types of storybooks (animal stories, fantasy stories ...) represented in the classroom?

- $\quad$ Are there differences in the style of the illustrations between the books?

- $\quad$ Are the main characters boys as well as girls?

- Is the book (psychologically) suitable for the age group?

- Can children identify with the main character or with any other character?

- Will there be links to their personal experiences?

- Is the book fun, has it got humor in it?

- How does the language match the children's language skills?

- Does the book match cross-curricular topics?

- Is it a book the children can read themselves?

- Is it a book they can read words or passages from?

- Is it a book they can understand without reading the text?

According to Vardel, Hadaway, and Young (2006: 735) the most important criteria in selecting books for learners 
English as a second language is that they are appropriate in relation to age, interests, and maturity.

\section{Teaching Young Learners through Story Books}

Stories contribute to children's language development. According to Winch et al. (2004: 402), children's literature "provides a wonderful opportunity for children to see language in action", "a great resource for more formal learning about the structures of language", and " a locus for learning about these structures in meaningful contexts". Children love stories. They ----

- $\quad$ are always eager to listen to stories

- $\quad$ know how stories work

- $\quad$ want to understand what is happening

- $\quad$ can enjoy hearing stories in English when they start English lessons.

- $\quad$ enjoy looking at storybooks by themselves

- $\quad$ can reread the stories they like when they read in English themselves.

(Slatterly \& Willis, 2001)

Heide Niemann (2002) lists the importance of storybooks as:

- $\quad$ Storybooks are part of a country's culture and thus they combine language learning and cultural awareness.

- Storybooks are challenging the imagination.

- $\quad$ Storybooks help children expand their own world, sometimes they may even help them cope with their reality.

- $\quad$ Storybooks provide language in a meaningful context.

- $\quad$ Storybooks provide grammatical structures in an authentic context.

- $\quad$ Storybooks provide children with the possibility to browse, choose their own pace, look carefully at details.

- $\quad$ Storybooks introduce topics and language in a child oriented way.

- $\quad$ Storybooks help children develop creative powers.

- In picture books the combination of a text and illustration is supportive for the understanding and the interpretation of a story.

Stories are useful in language learning for young learners. "Young learners acquire language unconsciously. The activities you do in class should help this kind of acquisition. Stories are the most valuable resource you have. They offer children a world of supported meaning that they can relate to. Later on you can use stories to help children practise listening, speaking, reading, and writing" (Slatterly \& Willis, 2001). Story telling can be effective for teaching English to young learners for the following reasons.

- $\quad$ The purpose of telling a story is genuinely communicative.

- $\quad$ Storytelling is linguistically honest (It is oral language, meant to be heard).

- $\quad$ Storytelling is real (people do it all the time).

- Storytelling appeals to the affective domain.

- Storytelling caters to the individual while forging a community in the classroom.

- $\quad$ Storytelling provides listening experiences with reduced anxiety.

(Curtain \& Dahlberg, 2004)

$\mathrm{Xu}(2003)$ states that literature in English can provide language learners with opportunities to master structure through exposure to repeated and predictable linguistic patterns. Huck et al. (1997:12) claim that "literature plays an important role in all aspects of oral language development. When young children are read to their own phonological production- the number and range of sounds that they produce-increases significantly", and "reading aloud has significant effects on the complexity of children's sentence structure and expository text". Gambrell et al. (2000:2) lists the characteristics of their approach to literature-based instruction as:

- $\quad$ Literature is used as an important vehicle for language arts instruction

- $\quad$ High quality narrative and informational literature provides the basis for a consistent read-aloud program in which children read daily 
a basal program.

Literature is the sole or primary basis for initial reading instruction, or it is a significant supplement to

- $\quad$ Opportunities are provided for students to listen to and read books of their own choosing.

- Students are provided with sustained time for both independent and collaborative book sharing, reading and writing activities.

- $\quad$ Discussions of literature among students and teachers are commonplace.

"Children delight in imagination and fantasy. It is more than simply a matter of enjoyment, however, in the language classroom this capacity for fantasy and imagination has a very constructive part to play" (Halliwell, 1993: 7). "Stories may bridge the gap between language study and language use and also to link classroom learning with the world outside. Some of the activities do not always have a very large language element but are nevertheless important in creating a feeling among the pupils that learning English means fun, activity, creativity and enjoyment". (Ellis \&Brewster 2002: 17)

Repetition of stories enables young learners master the language better. "Children enjoy listening to stories over and over again. This frequent repetition allows certain language items to be acquired while others are being overtly reinforced. Many stories contain natural repetition of key vocabulary and structures. This helps children to remember every detail, so they can gradually learn to anticipate what is about to happen next in the story. Repetition also encourages participation in the narrative" (Ellis \&Brewster, 2002: 2).

Stories are motivating, challenging and great fun for young learners. They "can help develop positive attitudes towards the foreign language, culture and language learning”(Ellis and Brewster, 2002:1). Winch et al. (2004:401) states that through literature-based activities "guided discussion promotes many literate oracy behaviours: it improves vocabulary, offers opportunities for more sophisticated sentence constructions and syntax, and lets the children hear the sounds of words as their peers say them". Fox (1993:185), about literature based instruction, writes "storytelling and hearing stories read aloud, expose children to linguistic and narrative conventions in the course of the power and pleasure they experience in the play". Using "stories allows the teacher to introduce or revise new vocabulary and sentence structures by exposing the children to language in varied, memorable and familiar contexts, which will enrich their thinking and gradually enter their own speech" (Ellis \&Brewster, 2002:2). "Listening to stories helps children become aware of the rhythm, intonation and pronunciation of language" (Ellis and Brewster, 2002:2). About literature for children Ferguson and Young (1996:598) claim that "(literature) provide language-rich illustrations of the uses of dialogue and often elicits a "chime in" response from students, thus providing a natural link to the give and take of conversation, vocabulary usage, and appropriate syntactical structure".

Young learners exercise their imagination through stories. They "can become personally involved in a story as they identify with the characters and try to interpret the narrative and illustrations. This imaginative experience helps" (Ellis \& Brewster, 2002:1) students develop their own creative potential.

Stories also "develop the different types of 'intelligences' that contribute to language learning, including emotional intelligence" (Ellis \&Brewster, 2002:2). Stories “develop children's learning strategies such as listening for general meaning, predicting, guessing meaning and hypothesizing" (Ellis \&Brewster, 2002:2). "Learning English through stories can lay the foundations for secondary school in terms of learning basic language functions and structures, vocabulary and language learning skills" (Ellis \&Brewster, 2002:2).

"It seems a pity to deprive learners of opportunities to hear authentic uses of past tense forms and contrast with the other tenses, in the meaningful contexts of stories, and I can see no intrinsic reason for supposing that use of past tense would prevent children understand a story. In fact, if they are familiar with stories in their first language, they will probably expect to hear past tense forms and may misconstrue the verbs" (Cameron, 2001: 166). According to Hsieh (2006), storytelling combined with total physical response can motivate young learners and is beneficial to their learning of English vocabulary, sentence patterns, and comprehension.

For teachers stories allow "to use an acquisition-based methodology by providing optimal input" (Ellis \& Brewster, 2002:2). It is great to use real storybooks because they "add variety and provide a springboard for creating complete units of work that constitute mini-syllabuses and involve pupils personally, creatively and actively in an all-round whole curriculum approach. They thereby provide a novel alternative to the course book" (Ellis \& Brewster, 2002:2). A Canadian critic, Michele Landsberg (1987) writes:

Good books can do so much for children. At their best, they expand horizons and instil in children a sense of the wonderful complexity of life. No other pastime available to children is so conductive to empathy and the enlargement of the human sympathies. No other pleasure can so richly furnish a child's mind with the symbols, patterns, depths, and possibilities of civilisation (p.34). 
The following are some recommended storytelling techniques from Brewster, Ellis \& Girard (2004).

- If students are unfamiliar are with storytelling, begin with short sessions which do not demand too much from them and over-extend their concentration span.

- $\quad$ Read slowly and clearly. Give your pupils time to relate what they hear to what they see in the pictures, to think, ask questions, make comment. However, do vary the pace when the story speeds up.

- Make comments about the illustrations and point to them to focus the pupils' attention

- $\quad$ Encourage your pupils to take part in the storytelling by repeating key vocabulary items and phrases. You can invite them to do this by pausing and looking at them with a questioning expression and by putting your hand to your ear to indicate that you are waiting for them to join in. Then repeat what they have said to confirm that they have predicted correctly, and if appropriate, expand by putting the word into a full phrase or sentence.

- $\quad$ Use gestures, mime, facial gestures to help convey the meaning.

- $\quad$ Vary the pace, tone, and volume of your voice. Are you going to whisper to build up suspense? Are you going to introduce an element of surprise by raising your voice?

- $\quad$ Pause where appropriate to add dramatic effect or to give children time to relate what they hear to what they see, and to assimilate details in the illustrations.

- $\quad$ Disguise your voice for the different characters as much as you can to signal when different characters are speaking and help convey meaning.

- $\quad$ Ask questions to involve children. What do you think is going to happen next? What would you do?

- Do not be afraid to repeat, expand and reformulate. This increases opportunities of exposure to the language and gives children a second chance to work out the meaning and have it confirmed.

(Shin)

\section{Conclusion}

Stories are motivating for young learners, and stories can create a happy and enjoyable learning environment. Stories are the most ideal sources for young learners in effective language learning. Children like stories, and they find stories easy to access and understand. Stories provide an outstanding opportunity for young learners to master the foreign language.

\section{References}

Ai Lian Kim. (2008). Teaching children through stories. Retrieved January 10, 2012, from http://www.cut-theknot.org/Education/teaching_children_throughstories.html

Brewster, J., Ellis, G., \& Girard, D. (2004). The primary English teacher's guide. London: Penguin.

Brown, E. Using children's literature with young learners. Retrieved January 12, 2012, from http://iteslj.org/Techniques/Brown=Children'sLit.html

Cameron, Lynne. (2001). Teaching languages to young learners. Cambridge: Cambridge Language Teaching Library.

Curtain, H., \& Dahlberg, C. A. (2004). Languages and children: making the match. Boston: Pearson.

ELLIS, Gail, \& BREWSTER, Jean. (2002). Tell it Again! Penguin, ISBN: 0-582-44777-1.

Ferguson, P. M., \& Young, T. A. (1996). Literature talk: Dialogue improvisation and patterned conversations with second language learners. Language arts, 73(8), 597-600.

Fox, C. (1993). At the very edge of the forest: the influence of literature on storytelling by children. London: Cassell.

Galda, L., \& Cullinan, B. E. (2002). Cullinan and Galda's literature and the child. Belmont, CA: Wadsworth/Thomson Learning.

Gambrell, J. B., Morrow, L. M., \& Pennington, C. (2000). Early childhood and elementary literature-Based instruction: Current perspectives and special issue. Reading Online, 5(6).

Garvie, Edie. (1991). "Teaching English through story" in: Kennedy, Chris, and Jarvis, Jennifer: Ideas and issues in primary ELT. Walton-on-Thames: The centre for British teachers. pp. 56-65.

Ghosn, I. K. (2002). Four good reasons to use literature in primary school. ELT journal, 56(2), 172-179. 
http://dx.doi.org/ 10.1093/elt/56.2.172

Halliwell, Susan. (1993). Teaching English in the primary classroom. London: Longman.

Hollindale, P. (1997). Signs of childness in children's books. Stroud: Thimble.

Hsieh, L. (2006). The application of TPR storytelling to children's English instruction. Paper presented at the $23^{\text {rd }}$ international conference on English teaching and learning in the Republic of China, Wenzao Ursiline College of languages.

Huck, C. S., Hepler, S., Hickman, J., \& Kiefer, B. Z. (1997). Children’s literature in the elementary school. Boston, MA: McGraw-Hill.

Landsberg, M. (1987). Reading for the love of it: Best books for young readers. New York: Prentice Hall.

Lewis, D. (2001). Reading contemporary, picture books. New York: RoutledgeFalmer.

McDowell, M. (1973). Fiction for children and adults: some essential differences. Children's literature in education, 10, 50-53. http://dx.doi.org/ 10.1007/BF01135994

Morrow, L. M. (1992). The impact of a literature-based program on literacy achievement, use of literature, and attitudes of children from minority backgrounds. Reading Research Quarterly, 27(3), 250-275. http://dx.doi.org/10.1598/RRQ.32.1.4

Mourao, Sandie. (2009). Using stories in the primary classroom. BritLit: Using literature in EFL classrooms, London.

Niemann, Heide. (2002). Mit bilderbuchern English lernen. Seelze -Velber: Kallmeyer.

Shin, Joan Kang. Teaching English to Young learners. University of Maryland.

Slatterly, M., \& Willis, J. (2001). English for primary teachers. Oxford: Oxford University Press.

Smallwood, B. A. (1988). Using multicultural children's literature in adult ESL classes. Digest, National Center for ESL literacy Education.

Steinbeck, Piotr. (2008). Using stories with young learners 2. Pearson Education.

Tomlinson, C. M., \& Lynch-Brown, C. (2002). Essentials of children's literature. Boston: Allyn and Bacon.

Vardell, S. M., Hadaway, N. L., \& Young, T. A. (2006). Matching books and readers: Selecting literature for English learners. Reading Teacher, 59(8), 734-741. http://dx.doi.org/10.1598/RT.59.8.1

Weinreich, T., \& Bartlett, D. (2000). Children's literature: art or pedagogy? Roskilde University Press.

Winch, G., Johnston. R. R., March P., Ljungdahl L., \& Holliday, M. (2004). Literacy Reading, writing, and children's literature. Melbourne: Oxford University Press.

Wright, A. Introduction in Paran, A. \& Watts, E. (Eds.). (2003). Storytelling in ELT. (Whitstable, IATEFL).

$\mathrm{Xu}, \mathrm{S}$. H. (2003). The learner, the teacher, the text and the context: Sociocultural approaches to early literacy instruction for English language learners. In D.M. Barone \& L.M. Morrow (Eds), Literacy and young children (61-80). New York; London: The Guilford Press. 